\title{
Analisis sifat kimia Velva terong ungu (Solanum Melongenal) Dengan Fortifikasi sari buah markisa (Passiflora edulis var. Flavicarpa)
}

\author{
Afifudin Ibadi, Wiwik Wahyuni*, Laili Hidayati \\ Universitas Negeri Malang, Jl. Semarang No. 5 Malang, Jawa Timur, Indonesia \\ *Penulis korespondensi, wiwik.wahyuni12@gmail.com
}

Paper received: 03-04-2021; revised: 17-04-2021; accepted: 20-04-2021

\begin{abstract}
Purple eggplant is a vegetable that is commonly cultivated in Indonesia. Product innovation is needed to increase people's consumption of eggplants, such as being made into Velva. Purple eggplant has the potential to be used as a raw material for making Velva because it has a thick pulp. The processing of Velva can reduce the nutritional content of purple eggplant. The fortification of passion fruit juice in this study is expected to increase the nutritional value of purple eggplant Velva. The research method used a completely randomized design with two repetitions and three levels of concentration of passion fruit juice fortification, namely 10 percent, 20 percent, 30 percent. Observation parameters included vitamin C content, dietary fiber, and antioxidant capacity. The data from the analysis were statistically tested using ANOVA. If a difference is found, then proceed with Duncan's Multiple Range Test (DMRT). Based on the results of the study, the concentration of 30 percent passion fruit juice fortification showed the highest results for the content of vitamin $\mathrm{C}$ and total dietary fiber, namely vitamin C $17.144 \mathrm{mg} / 100 \mathrm{gr}$ and total food fiber of 42.481 percent. The highest IC50 content was obtained from the fortification concentration of $10 \%$ passion fruit juice with a value of $92.338 \mathrm{ppm}$.
\end{abstract}

Keywords: purple eggplant; passion fruit juice; velva; fortification; chemical properties

\begin{abstract}
Abstrak
Terong ungu merupakan sayuran yang sudah umum dibudidayakan di Indonesia. Perlu adanya inovasi produk untuk meningkatkan konsumsi masyarakat terhadap terong, seperti dibuat menjadi velva. Terong ungu berpotensi digunakan sebagai bahan baku pembuatan velva karena memiliki daging buah yang tebal. Proses pengolahan pada velva dapat menurunkan kandungan gizi pada terong ungu. Fortifikasi sari buah markisa pada penelitian ini diharapkan dapat meningkatkan nilai gizi velva terong ungu. Metode penelitian menggunakan Rancangan Acak Lengkap dengan dua kali pengulangan dan tiga tingkatan konsentrasi fortifikasi sari buah markisa, yaitu 10 persen, 20 persen, 30 persen. Parameter pengamatan meliputi kandungan vitamin $C$, serat pangan, dan kapasitas antioksidan. Data hasil analisis diuji statistik menggunakan ANOVA. Apabila ditemukan perbedaan, kemudian dilanjutkan dengan uji Duncan's Multiple Range Test (DMRT). Berdasarkan hasil penelitian, konsentrasi fortifikasi sari buah markisa 30 persen menunjukkan hasil tertinggi untuk kandungan vitamin C dan serat pangan total, yaitu vitamin C $17,144 \mathrm{mg} / 100 \mathrm{gr}$ dan serat pangan total 42,481 persen. Kandungan IC50 tertinggi diperoleh dari konsentrasi fortifikasi sari buah markisa 10 persen dengan nilai 92,338 ppm.
\end{abstract}

Kata kunci: terong ungu; sari buah markisa; velva; fortifikasi; sifat kimia

\section{Pendahuluan}

Terong ungu (Solanum melongena L.) merupakan tanaman yang sudah lama dikenal di Indonesia (Silitonga dan Sitorus, 2014). Di dalam terong ungu terdapat pigmen antosianin yang sangat bermanfaat untuk tubuh manusia, yaitu sebagai antioksidan, dan dapat menurunkan kadar kolestrol dalam tubuh (Basnuy dkk, 2012). Menurut Annisa dkk (2011), kandungan gizi 
terong ungu di antaranya vitamin $\mathrm{C}$ dan serat. Perlu adanya inovasi produk untuk meningkatkan daya konsumsi masyarakat terhadap terong (Nurwerstin \& Samaduri, 2017).

Velva merupakan salah satu jenis makanan frozen dessert yang berbahan baku buahbuahan dan dibekukan dengan alat pembekuan es krim (Maria dan Zubaidah, 2014). Terong ungu memiliki daging yang tebal sehingga dapat digunakan sebagai bahan dasar pembuatan velva. Menurut Ermawati (2018), pembuatan velva terdiri dari beberapa tahap, mulai dari pemilihan buah (sortasi), pencucian, pemotongan, blanching, penghancuran, pencampuran, pendinginan, pembekuan, dan penyimpanan. Proses pemanasan pada pembuatan velva dapat menurunkan kandungan gizi pada terong ungu. Penambahan sari buah markisa diharapkan dapat meningkatkan nilai gizi pada velva terong ungu. Buah markisa juga bisa ditambahkan untuk memperkaya rasa dan aroma pada suatu produk olahan (Siman. dkk, 2016).

\section{Metode}

Rancangan penelitian dalam penelitian ini adalah Rancangan Acak Lengkap (RAL) dengan perlakuan persentase fortifikasi sari buah markisa 10\%, 20\%,30\% dan diulang sebanyak dua kali. Analisis dilakukan terhadap kandungan vitamin $\mathrm{C}$, serat pangan, dan kapasitas antioksidan. Analisis vitamin C dilakukan dengan metode Jacob iodimetri, serat pangan dengan metode Enzymatic digestion, kapasitas antioksidan dengan metode DPPH spektofotometri. Formula velva terong ungu dengan fortifikasi sari buah markisa dapat dilihat pada Tabel 1.

Tabel 1. Formula Velva Terong Ungu dengan Fortifikasi Sari Buah Markisa

\begin{tabular}{lllll}
\hline No & Bahan & Formula 1 & Formula 2 & Formula 3 \\
\hline 1 & Terong ungu & $250 \mathrm{~g}$ & $250 \mathrm{~g}$ & $250 \mathrm{~g}$ \\
2 & Sari buah markisa & $25 \mathrm{~g}(10 \%)$ & $50 \mathrm{~g}(20 \%)$ & $75 \mathrm{~g}(30 \%)$ \\
3 & CMC & $5 \mathrm{~g}$ & $5 \mathrm{~g}$ & $5 \mathrm{~g}$ \\
4 & Gula & $150 \mathrm{~g}$ & $150 \mathrm{~g}$ & $150 \mathrm{~g}$ \\
5 & Air & $250 \mathrm{ml}$ & $250 \mathrm{ml}$ & $250 \mathrm{ml}$ \\
\hline
\end{tabular}

Alat yang digunakan dalam proses pembuatan velva terong ungu dengan fortifikasi sari buah markisa adalah timbangan digital, baskom, pisau, gelas ukur, saringan, sendok, kompor, panci, termometer, blender, votator, freezer. Alat analisis vitamin C menggunakan Erlenmeyer, pipet tetes, labu ukur, dan gelas ukur. Alat analisis serat pangan menggunakan Soxhlet, neraca analitik, erlenmeyer, penangas air, $\mathrm{pH}$ meter, alumunium foil, cruible, oven. Alat analisis kapasitasantioksidan menggunakan Rotary evaporator, spektrofotometri UV-vis, neraca analitik, timbangan kasar, botol vial, blender, gelas ukur, gelas beker, oven dan pipet tetes. Data hasil analisis diuji statistik menggunakan ANOVA. Apabila ditemukan perbedaan, kemudian dilanjutkan dengan uji Duncan's Multiple Range Test (DMRT).

\section{Hasil dan Pembahasan}

\subsection{Vitamin C}

Hasil analisis kandungan vitamin $\mathrm{C}$ velva terong ungu dengan fortifikasi sari buah markisa dapat dilihat pada Tabel 2 . 
Tabel 2. Rerata Kandungan Vitamin C Velva Terong Ungu dengan Fortifikasi Sari Buah Markisa

\begin{tabular}{lllll}
\hline \multirow{2}{*}{ Sampel } & \multicolumn{2}{c}{ Vitamin C (mg/100gr) } & Total & Rerata \\
\cline { 2 - 5 } & \multicolumn{1}{c}{$\mathbf{1}$} & $\mathbf{2}$ & & \\
\hline $10 \%$ & 9,678 & 11,425 & 21,103 & 10,552 \\
$20 \%$ & 13,188 & 13,191 & 26,379 & 13,190 \\
$30 \%$ & 16,710 & 17,577 & 34,287 & 17,144 \\
\hline
\end{tabular}

Hasil uji DMRT menunjukkan bahwa kandungan vitamin C pada velva terong ungu dengan fortifikasi sari buah markisa berbeda nyata antara konsentrasi yang satu dengan konsentrasi yang lain. Vitamin C mengalami peningkatan seiring dengan semakin banyaknya konsentrasi fortifikasi sari buah markisa. Kandungan vitamin $\mathrm{C}$ diduga karena terong ungu dan markisa mengandung vitamin $\mathrm{C}$ yang tinggi.

\subsection{Serat Pangan Total}

Hasil analisis kandungan serat pangan total velva terong ungu dengan fortifikasi sari buah markisa dapat dilihat pada Tabel 3.

Tabel 3. Rerata Kandungan Serat Pangan Total Velva Terong Ungu dengan Fortifikasi Sari Buah Markisa

\begin{tabular}{|c|c|c|c|c|}
\hline \multirow{2}{*}{ Sampel } & \multicolumn{2}{|c|}{ Serat pangan total (\%) } & \multirow[t]{2}{*}{ Total } & \multirow[t]{2}{*}{ Rerata } \\
\hline & 1 & 2 & & \\
\hline $10 \%$ & 30,179 & 31,437 & 61,616 & 30,808 \\
\hline $20 \%$ & 35,114 & 36,417 & 71,531 & 35,766 \\
\hline $30 \%$ & 41,741 & 43,220 & 84,961 & 42,481 \\
\hline
\end{tabular}

Hasil uji DMRT menunjukkan bahwa kandungan serat pangan total pada velva terong ungu dengan fortifikasi sari buah markisa berbeda nyata antara konsentrasi yang satu dengan konsentrasi yang lain. Serat pangan mengalami peningkatan seiring dengan semakin banyaknya konsentrasi fortifikasi sari buah markisa. Kandungan serat pangan diduga karena terong ungu dan markisa mengandung serat pangan. Terung ungu mengandung serat pangan, antara lain selulosa, hemiselulosa, lignin, senyawa pektin, getah, dan gula polisakarida (Hintono, 2017). Menurut Sunarti (2017) markisa mengandung serat pangan dalam bentuk hemiselulosa.

\subsection{Kapasitas Antioksidan}

Hasil analisis kapasitas antioksidan velva terong ungu dengan fortifikasi sari buah markisa dapat dilihat pada tabel 4 .

Tabel 3. Rerata Kapasitas Antioksidan Velva Terong Ungu dengan Fortifikasi Sari Buah Markisa

\begin{tabular}{lcccc}
\hline \multirow{2}{*}{ Sampel } & \multicolumn{2}{c}{ IC50 (ppm) } & Total & Rerata \\
\cline { 2 - 5 } & $\mathbf{1}$ & $\mathbf{2}$ & & \\
\hline $10 \%$ & 93,141 & 91,535 & 184,676 & 92,338 \\
$20 \%$ & 83,561 & 81,746 & 165,307 & 82,654 \\
$30 \%$ & 73,467 & 72,206 & 145,673 & 72,837 \\
\hline
\end{tabular}


Hasil uji DMRT menunjukkan bahwa IC50 pada velva terong ungu dengan fortifikasi sari buah markisa berbeda nyata antara konsentrasi yang satu dengan konsentrasi yang lain. IC50 mengalami penurunan seiring dengan semakin banyaknya konsentrasi fortifikasi sari buah markisa. Semakin rendah IC50 maka semakin kuat kapasitas antioksidan (Sinaga, 2009). Kapasitas antioksidan diduga karena terong ungu dan markisa mengandung senyawa antioksidan. Basnuy dkk (2012) mengatakan bahwa di dalam terong ungu terdapat pigmen antosianin yang sangat bermanfaat untuk tubuh manusia. Hasil skrining fitokimia yang dilakukan Martiningsih,dkk (2014) menunjukkan bahwa ekstrak etanol buah terong ungu positif mengandung senyawa golongan alkaloid dan flavanoid. Berdasarkan hasil penelitian dari Armin. dkk (2014), buah markisa memiliki kadar senyawa fenolat yang berkhasiat sebagai antioksidan.

\section{Simpulan}

Konsentrasi fortifikasi sari buah markisa pada velva terong ungu berpengaruh terhadap kandungan vitamin C, kandungan serat pangan, dan kapasitas antioksidan. Kandungan vitamin $\mathrm{C}$ dan serat pangan tertinggi diperoleh dari velva terong ungu dengan konsentrasi fortifikasi sari buah markisa 30\%, sedangkan angka (IC50) tertinggi diperoleh dari velva terong ungu dengan konsentrasi fortifikasi sari buah markisa $10 \%$.

\section{Saran}

Berdasarkan hasil penelitian sifat kimia velva terong ungu dengan fortifikasi sari buah markisa yang meliputi kandungan vitamin C, serat pangan, dan kapasitas antioksidan, dapat disarankan untuk penelitian lanjutan tentang uji sifat fisik (overrun, kecepatan leleh), uji sifat organoleptik, dan perlakuan untuk memperbaiki rasa langu agar mendapatkan formula velva terbaik sesuai Standar Nasional Indonesia.

\section{Daftar Rujukan}

Annisas, A. J. Nurul, S \& Putri, P. 2011. Terung Ungu (Solanum melongena L.) sebagai Tablet Kontrasepsi Hisap Khusus Pria dalam Mendukung Program KB (Keluarga Berencana). Bogor: Institul Pertanian Bogor. Dari http://repository.ipb.ac.id/bitstream /handle/123456789/44233/PKM-GT-11IPB-JanuarTerung\%20Ungu\%20Sebagai.pdf?sequence=2

Armin, F. Ermadani. Roslinda, R. 2014. Analisis Senyawa Fenolat dan Uji Aktivitas Antioksidan Buah Markisa (Passiflora edulis Sims) Secara Spektrofotometri Visibel. Jurnal Farmasi Higea, 4(2), 117-128.

Basnuy, A. M. M. Arafat, S. M. \& Marooq, M. A. 2012. Antioksidant and Anthiperlipidemic Activities of Anthocyanins from Eggplants Peels.

Ermawati, D. A. 2018. Pengaruh Penambahan Pewarna Alami Sari Buah Naga Merah (Hylocereus Polyrhizus) Terhadap Mutu Fisikokimia Velva Pisang Awak (Musa Paradisiaca L. Var. Awak). Skripsi Tidak Diterbitkan. Malang: Universitas Negeri Malang.

Hintono, A. Pramono, Y. B. 2017. Pengaruh Lama dan Suhu Pengeringan terhadap Sifat Fisik dan Kimiawi Tepung Terung Ungu (solanum melongena L.). Semarang: Universitas Diponegoro. Dari http://eprints.undip.ac.id/55533/3/Bab_II.pdf

Maria, D. N. \& Zubaidah, E. 2014. Pembuatan Velva Jambu Biji Merah Probiotik (Lactobacillus Acidophillus) Kajian Persentase Penambahan Sukrosa Dan CMC. Jurnal Pangan dan Agroindustri, 2(4), 18-28. Dari https://jpa.ub.ac.id/index.php/jpa/article/view/74

Martiningsih, N. W. Sukarta, I. N. \& Yuniana, P. E. 2014. Skrining Fitokimia dan Uji Aktivitas Antioksidan dari Ekstrak Etanol Buah Terong Ungu (Solanum Melongena L.). Jurnal Kimia, 8(2), 145-152. Dari ojs.unud.ac.id/index.php/jchem/article/view/11747

Nurwerstin, E. \& Samaduri, L. 2017. Pelatihan Pembuatan Keripik Terong. Jurnal Pengabdian Masyarakat, 1(1), 1-5. Dari http://lonsuit.unismuhluwuk.ac.id/index.php/monsuan/article/view/241

Silitonga, P. \& Sitorus, B. 2014. Enkapitulasi Pigmen Antosianin dari Kulit Terong Ungu. Jurnal Kimia Khatulistiwa, 3(1). 44-49. 
Jurnal Inovasi Teknik dan Edukasi Teknologi, 1(4), 2021, 269-273

Siman, A. R. Ekawati, L. M. \& Swasti, Y. R. 2016. Aktivitas Antioksidan dan Kualitas Yoghurt dari Kombinasi Sari Kacang Tunggak (Vigna Unguiculata) dan Sari Buah Markisa Kuning (Passiflora Edulis var. Flavicarpa).

Sinaga, I. 2009. Skrining Fitokimia dari Uji Aktivitas Antioksidan dari Ekstrak Etanol Buah Terong Belanda (Solanum betaceum Cav.). Dari http://repository.usu. ac.id/bitstream/123456789/14449/1/09E026 36.pdf.

Sunarti, 2017. Serat Pangan dalam Penanganan Sindrom Metabolik. Sleman: Gadjah Mada University Press. 